\title{
Acute skin toxicity management in head and neck cancer patients treated with radiotherapy and chemotherapy or EGFR inhibitors: Literature review and consensus
}

Elvio G. Russi ${ }^{\mathrm{a}, *}$, Francesco Moretto ${ }^{\mathrm{b}}$, Monica Rampino ${ }^{\mathrm{b}}$, Marco Benasso ${ }^{\mathrm{c}}$, Almalina Bacigalupo $^{\mathrm{d}}$, Vitaliana De Sanctis ${ }^{\mathrm{e}}$, Gianmauro Numico ${ }^{\mathrm{f}}$, Paolo Bossi ${ }^{\mathrm{g}}$, Michela Buglione $^{\mathrm{h}}$, Antonino Lombardo ${ }^{\mathrm{i}}$, Mario Airoldi ${ }^{\mathrm{j}}$, Marco C. Merlano ${ }^{\mathrm{k}}$, Lisa Licitra ${ }^{\mathrm{g}}$, Nerina Denaro $^{\mathrm{k}}$, Stefano Pergolizzi ${ }^{1}$, Carmine Pinto ${ }^{\mathrm{m}}$, Renè- Jean Bensadoun ${ }^{\mathrm{n}}$, Giampiero Girolomoni ${ }^{\circ}$, Johannes A. Langendijk ${ }^{p}$

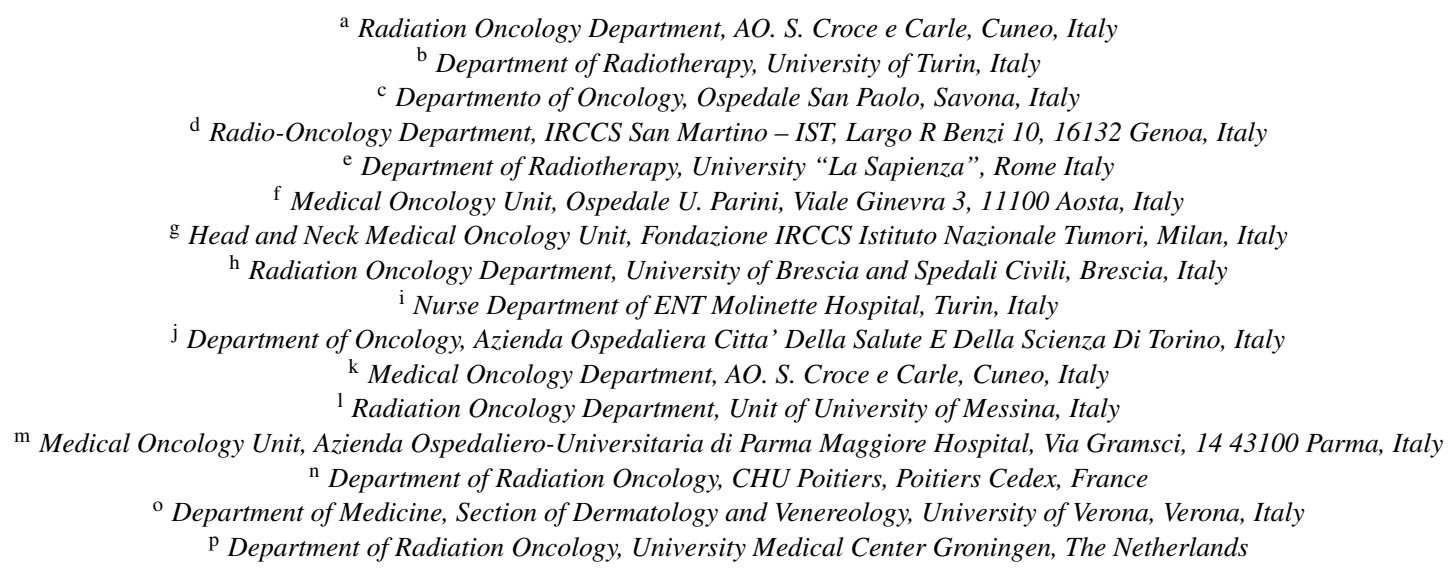

Accepted 4 June 2015

\section{Contents}

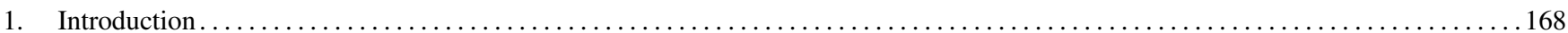

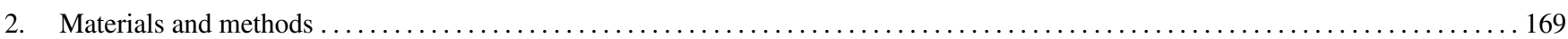

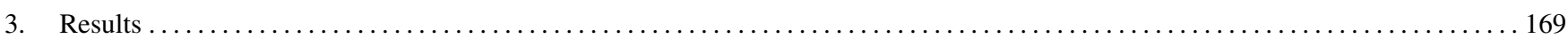

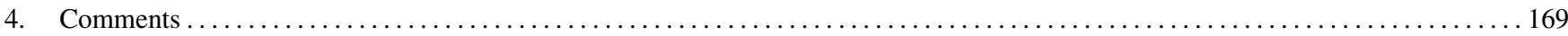

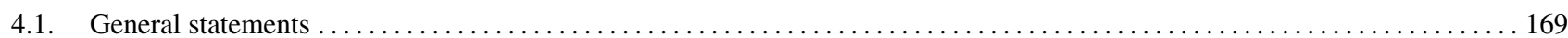

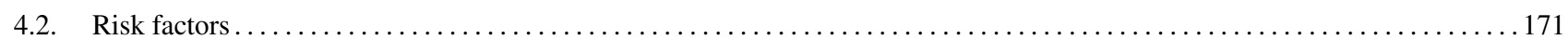

\footnotetext{
* Corresponding author. Tel.: +39 3280971299 .

E-mail addresses: elviorussi@gmail.com (E.G. Russi), moretto.francesco@hotmail.it (F. Moretto), monicaramp100@gmail.com (M. Rampino), m.benasso@gmail.com (M. Benasso), almalina.bacigalupo@hsanmartino.it (A. Bacigalupo), vitaliana.desanctis@uniroma1.it (V. De Sanctis), gnumico@ausl.vda.it (G. Numico), paolo.bossi@istitutotumori.mi.it (P. Bossi), michela.buglione@unibs.it (M. Buglione), alombardo@cittadellasalute.to.it (A. Lombardo), airoldim@yahoo.com (M. Airoldi), mcmerlano@gmail.com (M.C. Merlano), Lisa.Licitra@istitutotumori.mi.it (L. Licitra), nerinadenaro@gmail.com (N. Denaro), stpergolizzi@unime.it (S. Pergolizzi), cpinto@ao.pr.it (C. Pinto), Rene-Jean.BENSADOUN@chu-poitiers.fr (R.J. Bensadoun), giampiero.girolomoni@univr.it (G. Girolomoni), j.a.langendijk@rt.umcg.nl (J.A. Langendijk).
} 


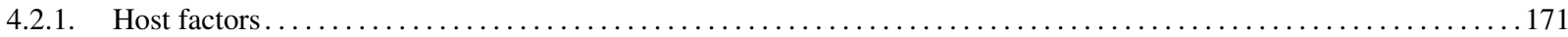

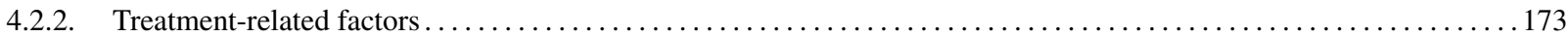

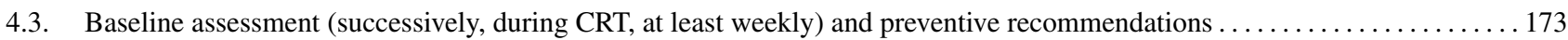

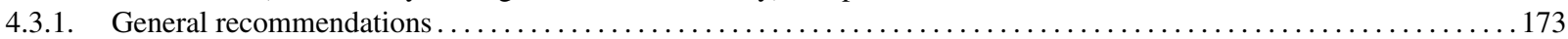

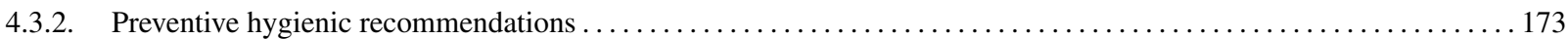

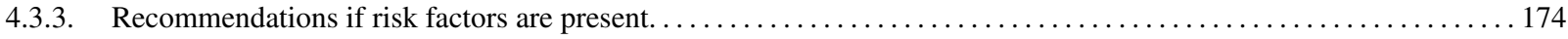

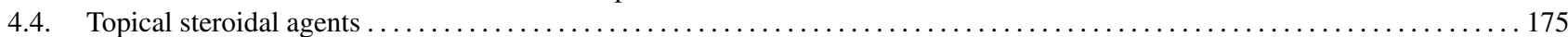

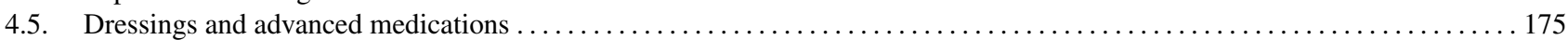

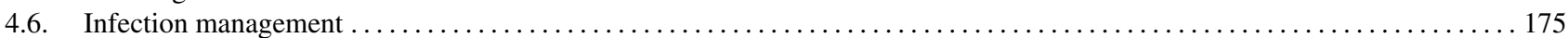

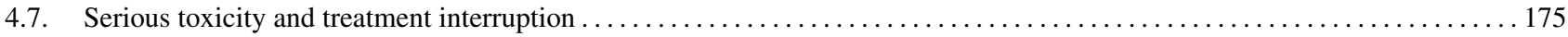

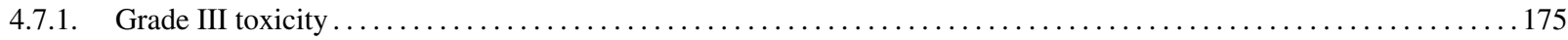

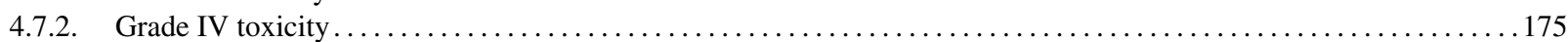

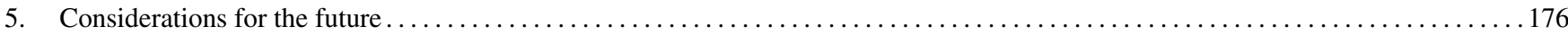

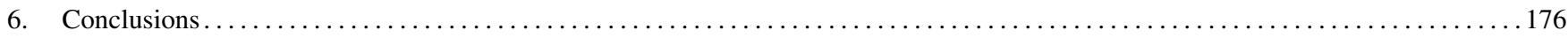

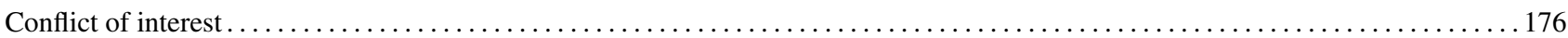

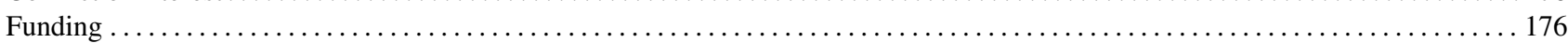

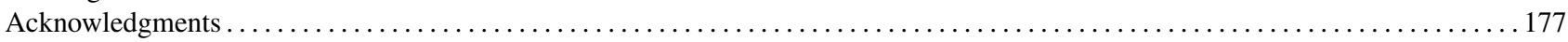

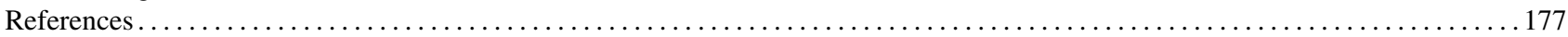

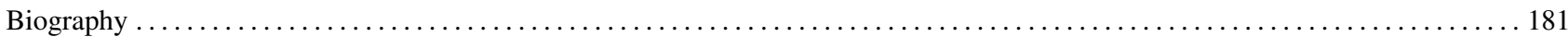

\begin{abstract}
The adverse effects of radiation therapy, often integrated with chemotherapy and/or targeted therapies, on the skin include severe acute and chronic dermatitis associated with pain, discomfort, itching, and burning, and may heavily affect patients' quality of life. The management of these skin adverse effects in head and neck cancer patients (HNCPs) are very heterogeneous due to the lack of shared rigorous classification systems and evidence based treatments.

A multidisciplinary group of head and neck cancer specialists from Italy met with the aim of reaching a consensus on a clinical definition and management of dermatitis in HNCPs treated with radiotherapy with or without systemic therapies in order to improve skin toxicity management. The Delphi Appropriateness Method was used. External expert reviewers then evaluated the conclusions carefully according to their area of expertise.

This paper offers contains seven clusters of statements about the management of dermatitis in HNCPs and a review of recent literature on these topics.
\end{abstract}

(c) 2015 Elsevier Ireland Ltd. All rights reserved.

Keywords: Skin toxicity; Radiotherapy; Cetuximab; Chemotherapy; Head and neck cancer; Biodermatitis; EGFRi

\section{Introduction}

The improvements in head and neck cancer (HNC) treatment have led to an increase in the overall response rate (ORR), progression-free survival (PFS), and overall survival (OS) [1].

Unfortunately, the use of radiation therapy, often integrated with chemotherapy and/or targeted therapies, must deal with severe acute and chronic skin toxicity often associated with pain, discomfort, itching, and burning, heavily affecting patients' quality of life [2-4].

Significant acute skin toxicity may affect up to $95 \%$ of these patients, which sometimes impacts negatively on the proper adherence to the treatment protocol [5].

Contemporary radiation technologies allow the skin to receive only a fraction of the total dose that is delivered to the target, but in the case of HNC the skin is so near target volumes that radio-dermatitis cannot be avoided.

Furthermore, the association of radio-sensitizing systemic therapies (e.g. 5-fluorouracil, Cetuximab, etc.) increases this toxicity $[3,6-8]$ and may modify the timing and clinical aspects of radio-dermatitis effects. For instance, radio-induced dry desquamation may be aggravated and its timing shortened by the Cetuximab-induced xerosis [9]. Similarly, radio-induced moist desquamation may be complicated by chemotherapy or epidermal growth factor receptor inhibitors that predispose HNCPs to systemic inflammation response [10] and to infection [11].

The management of these skin adverse effects in HNCPs is very heterogeneous because of the lack of shared rigorous classification systems and evidence based treatments. A recent study from Belgium [12] showed that the disclosure and implementation of a skin protocol enhanced standardization in Flanders improved adhesion to evidence-based guidelines and led to the disappearance of out-dated ritualistic practices.

For all these reasons Italian medical oncologists, radiation oncologists and nurses met with the aim of reaching a consensus on a clinical definition and management of acute 
radiation dermatitis in HNCPs, particularly in regard to those statements with limited evidence.

The results of the literature review and the statements that obtained a consensus are reported and discussed in this paper.

\section{Materials and methods}

The Delphi Appropriateness method was used for this Consensus [13].

The panel, a group of 32 multidisciplinary experts (medical oncologists, radiation oncologists, dermatologists, nutritionists, and nurses), met in Milan on February 17th-18th, 2013 and appointed a facilitator board of six expert members, from different clinical settings (three radiation oncologists, 1 medical oncologist, and two nurses). The facilitator board performed a systematic review of the literature on skin toxicity.

The MEDLINE database was searched for studies published from 1990 to March 2013 containing the terms skin toxicity, skin reaction, actinic dermatitis, head and neck cancer, chemotherapy, Cetuximab and radiotherapy (RT). The literature search was limited to articles in Italian, English and French about human cancers treated with RT.

Potentially relevant abstracts presented at annual meetings of the American Society of Clinical Oncology (ASCO), American Society for Radiation Oncology (ASTRO) and the European Society of Medical Oncology (ESMO) were also examined.

The study selection included the following:

(a) Observational and prospective studies about assessment and treatment; (b) randomized, double-blind, placebocontrolled, or uncontrolled studies; (c) retrospective and uncontrolled studies; (d) systematic reviews and metaanalyses; and (e) consensus guidelines. Furthermore, the electronic search results were supplemented by manual examination of reference lists from selected articles.

On the basis of this literature review, the facilitators identified a number of key statements.

All the experts rated these statements through a two-round process. A scale of four steps was used, where 1 was defined as "high consensus", two was defined as "low consensus", three was defined as "no consensus", and four was chosen by panellists when they felt unable to express an opinion.

A web meeting was held before the second rating, where statements were discussed. The statements that received a weak or no approval (less than $75 \%$ of votes) were redefined according to the observations of panellists. The second ratings were analyzed to identify the statements that reached a consensus.

Each expert (including facilitators) was equally weighted in scoring the statements.

Then, external radiation oncologists (JAL, R-JB), a medical oncologist (CP), and a dermatologist (GG) reviewed the statements.
The panellists had a second meeting in Milan on 5 May 2014 in order to approve the final version of the statements.

\section{Results}

Consensus-reached statements are listed in Table 1

\section{Comments}

\subsection{General statements}

1. The most commonly-used RTOG/EORTC and CTCAE v.3-4.3 grading systems do not capture the symptoms or impact due to RT-associated systemic therapies on radiation dermatitis.

2. When it is necessary to capture symptoms, other scales, such as RISRAS or Skindex-16, could be used additionally $[2,4,14-16]$.

The use of a common, sensitive, specific, and easy tool is fundamental for the classification and the management of all possible skin toxicities.

Some commonly used grading tools for the assessment and documentation of radio-dermatitis include the Radiation Therapy Oncology Group (RTOG)/European Organization for Research and Treatment of Cancer (EORTC) toxicity criteria [17], the Common Terminology Criteria for Adverse Events, version 3 and 4.03 (CTCAE) [18,19], the Skin Toxicity Assessment Tool [20], the Radiation-Induced Skin Reaction Assessment Scale $[2,15]$, and the Skindex-16 scale [16].

Most of the tools are observer assessments that do not capture the symptoms or the skin-reaction impacts on Activities of Daily Living (ADL) or on the clinical management. On the contrary, the recent classification of CTCAE v. 4 published in May 2009 evaluates the impact of the Adverse Events on the patient's ADL and on the clinical management [21] (see Table 2).

3. When it is necessary to capture the impact of systemic biological therapy on radiation dermatitis, it is advisable to use the in-field bio-radiation skin-toxicity grading score.

Radiation dermatitis developing in patients receiving Cetuximab concomitantly with RT for locally advanced squamous cell $\mathrm{HNC}$ is now recognized as having different pathophysiological and clinical characteristics with respect to the radiation dermatitis due to $\mathrm{RT}$ alone [22,23].

While version 4 of the NCI "Cancer Therapy Evaluation Program" (CTCAE v.4) graded new systemic dermatological toxicities (e.g. "Rash acneiform" hierarchically grouped into the "Skin and subcutaneous tissue disorders" (System Organ Class), which are more appropriate for grading systemic EGFR-inhibitor (EGFRi) toxicities than previous versions $[24,25]$, there has not yet been any grading system which 
Table 1

Consensus-reached statements.

Cluster Description Whom is it in charge of?

Phase

1 Before CRT

2 Before CRT

3 Baseline evaluation

\section{General statements}

1. The most commonly-used RTOG/EORTC and CTCAE v.3-4.3 grading systems do not capture the symptoms or impact due to RT-associated systemic therapies on radiation dermatitis.

2. When it is necessary to capture symptoms, other scales, such as RISRAS or Skindex-16, could be used additionally.

3. When it is necessary to capture the impact of systemic biological therapy on radiation dermatitis, it is advisable to use the in-field bio-radiation skin-toxicity grading score

1. Risk factors (factors that place patients at increased risk of severe skin toxicity, and that should be considered at the baseline skin assessment) 1.1. Host factors:

1. Personal factors such as skin friction, nutritional status, age, race and ethnicity, sun exposure, smoking and pre-existing skin disease (such as atopic eczema or psoriasis, or autoimmune bullous diseases).

2. Co-morbidities (such as rheumatoid arthritis, lupus erythematosis, or scleroderma, etc.)

3. Diagnosis of gene repair disorders (for example Xeroderma pigmentosum, ataxia-telangiectasia, Fanconi anaemia, Nijmegen syndrome, etc.)

1.2. Treatment-related factors:

1. Skin total dose, Fraction size, type and energy of radiation and the use of bolus.

2. Chemotherapy or other medical photosensitizing concomitant therapies

2. Baseline assessment (successively, during CRT, at least weekly) and preventive recommendations

2.1. General recommendations:

1. A detailed medical history relating to personal and family risk factors should be carefully collected.

2. It is important to establish a proper technique to minimize the dose delivered to the skin.

3. Avoid radio-sensitizing drugs during radiation treatment, if clinically indicated: when chemotherapy is not concurrent (paclitaxel, docetaxel), a period of almost seven days has to be respected (see point $2 \mathrm{~b} 2$ ).

4. Caution must be used with non-necessary common photosensitizing drugs and sun exposure during chemo-radiation (see point $2 \mathrm{~b} 2$ ).

5. Patients must avoid smoking.

2.2. Preventive hygiene recommendations:

1. Washing with lukewarm water and a mild soap $(\mathrm{pH}$-neutral or non-alkaline soap) can be used as routine care for all patients receiving radiation therapy.

2. Shaving with a sharp, disposable multi-blade wet razor or with a non-traumatizing electric razor.

3. Avoid micro-traumas in irradiated area or tapes and adhesives.

4. Preventive non-steroidal treatments: A moisturizing cream based on urea or anionic polar phospholipid is advised. Trolamine and Aloe Vera are not recommended.

5. It is not advisable to use cream or other skin products from 1 to $4 \mathrm{~h}$ before treatment so as to avoid "build-up" effects.

2.3. Recommendations if risk factors are present.

1. Maintain an optimal control of co-morbidities as diabetes and nutritional status; a close collaboration with the diabetologist and the dietician is needed.

2. If active signs/symptoms of rheumatoid arthritis, systemic lupus erythematosis, psoriatic arthritis, or scleroderma are diagnosed, consider using conventional fractionation, reducing total dose where possible, keeping treatment volumes as small as possible and keeping a high level of caution with multimodality treatments, especially when RT is associated to concurrent chemotherapy or biological anticancer treatments. A close liaison with the rheumatologist and dermatologist is needed.

3. If gene repair disorders are diagnosed (for example Xeroderma pigmentosum, ataxia-telangiectasia, Fanconi anaemia, Nijmegen syndrome, etc.) consider avoiding RT.
Oncology Physician-Nurse

Oncology Physician-Nurse-Patient

Oncology Physician-Nurse-Patient 
Table 1 (Continued)

\begin{tabular}{|c|c|c|}
\hline $\begin{array}{l}\text { Cluster } \\
\text { Phase }\end{array}$ & Description & Whom is it in charge of? \\
\hline 4 During CRT & $\begin{array}{l}\text { 3. Topical steroidal agents } \\
\text { 1. The use of corticosteroid creams for treating itching or irritation should } \\
\text { be limited over time as they can cause thinning of the skin and bacterial } \\
\text { infections. } \\
\text { 2. The use of corticosteroid creams in the prevention of skin reactions is } \\
\text { not advisable as they can cause thinning of the skin and bacterial infections }\end{array}$ & Oncology Physician-Nurse \\
\hline 5 During CRT & $\begin{array}{l}\text { 4. Dressing and advanced medications } \\
\text { 1. Even though there is insufficient evidence to support a recommendation } \\
\text { for using dressings or advanced medications, these can be used to protect } \\
\text { irradiated skin from trauma or, in the case of wet desquamation, in order to } \\
\text { control pain, bleeding, and exudates. } \\
\text { 2. Protection of ulcerated parts can be provided with hydrocolloid films } \\
\text { after having cleaned the skin. The ultrathin films can be maintained during } \\
\text { radiation. This dressing should be removed when it is saturated with } \\
\text { exudate. } \\
\text { 3. Hydrofibers, calcium alginate dressings, and polyurethane or silicone } \\
\text { foams could be used when the exudate is very abundant. No evidence } \\
\text { exists to support one product over another. } \\
\text { 4. When crusts or crustose exudations are present, the debridement of } \\
\text { crusts may help to reduce the risk of super-infection and bleeding and may } \\
\text { help with pain management. }\end{array}$ & Oncology Physician-Nurse \\
\hline 6 During CRT & $\begin{array}{l}\text { 5. Infection management } \\
\text { 1. Consider topical or systemic antimicrobials if positive cultures or } \\
\text { documented infections are present. } \\
\text { 2. An empirical systemic antibiotic therapy must be used as soon as } \\
\text { possible when two altered parameters of Systemic Inflammatory Response } \\
\text { Syndrome (SIRS) and/or other signs of systemic inflammatory response to } \\
\text { infection (such as inflammatory, haemodynamic, organ dysfunction and } \\
\text { tissue perfusion parameters) coexist with a suspected infection }\end{array}$ & Oncology Physician-Nurse \\
\hline 7 During CRT & $\begin{array}{l}\text { 6. Serious toxicity and treatment interruption. } \\
\text { 6.1. Grade III toxicity } \\
\text { In the case of toxicity of grade } 3 \text { or less every effort should be made to } \\
\text { not stop the radiation treatment. } \\
\text { 6.2. Grade IV toxicity } \\
\text { 1. Consider interrupting both systemic and radiation treatments. If the } \\
\text { patient has been treated with Cetuximab and RT, Cetuximab should be } \\
\text { interrupted until the skin reaction has resolved to at least grade II } \\
\text { 2. Refer patient for wound care or wound specialist management. }\end{array}$ & Oncology Physician-Nurse \\
\hline
\end{tabular}

assesses the severity of Adverse Events (AEs) due to the association of bio-therapies with RT.

In 2011, Bernier et al. proposed a new classification [26] that considers the adverse effects of both radio-dermatitis and Cetuximab on "in-field" skin. The limits of this classification are the fact that it does not take into account the impact of the AEs on the patient's activities of daily living (ADL) and their impacts on the clinical management as required by CTCAE v.4. Furthermore, it considers only the effects of Cetuximab without considering the possibility that new biological anticancer therapies - with different AEs - might be used in the near future.

For this reason, a group of US and European experts [27] proposed a new classification that considers the CTCAE recommendations regarding ADL and that does not limit the grades exclusively to Cetuximab but extend them to the possible effects of new future biotherapies (at the moment non predictable) on the irradiated skin.
Even though the latter scale has not yet been validated [28], the panellists suggested adopting it, in the absence of a more appropriate one.

\subsection{Risk factors}

The factors that may influence the response of the patient's skin to RT have been grouped into two categories: host factors depending on the patient's biological characteristics and treatment-related factors. These factors may place the patient at increased risk of dermatitis and should be considered at the baseline skin assessment.

\subsubsection{Host factors}

1. Personal factors such as skin friction, nutritional status, age, race and ethnicity, sun exposure, smoking and preexisting skin disease (such as atopic eczema or psoriasis, or autoimmune bullous diseases). 
Table 2

In-field adverse events due to radiation therapy with or without biological therapies.

\begin{tabular}{|c|c|c|c|c|}
\hline & Grade 1 & Grade 2 & Grade 3 & Grade 4 \\
\hline $\begin{array}{c}\text { NCI-CTCAE, v4.03 } \\
\text { general criteria }\end{array}$ & $\begin{array}{l}\text { Mild; asymptomatic or } \\
\text { mild symptoms; } \\
\text { Clinical or diagnostic } \\
\text { observations only; } \\
\text { intervention not } \\
\text { indicated. }\end{array}$ & $\begin{array}{l}\text { Moderate; } \\
\text { Minimal, local or } \\
\text { non-invasive } \\
\text { intervention indicated; } \\
\text { Limiting } \\
\text { age-appropriate } \\
\text { instrumental ADL (refer } \\
\text { to preparing meals, } \\
\text { shopping for groceries } \\
\text { or clothes, using the } \\
\text { telephone, managing } \\
\text { money, etc. }\end{array}$ & $\begin{array}{l}\text { Severe or medically } \\
\text { significant but not } \\
\text { immediately life-threatening; } \\
\text { Hospitalization or } \\
\text { prolongation of } \\
\text { hospitalization indicated; } \\
\text { disabling; } \\
\text { Limiting self care AD (refer } \\
\text { to bathing, dressing and } \\
\text { undressing, feeding self, } \\
\text { using the toilet, taking } \\
\text { medications, and not } \\
\text { bedridden }\end{array}$ & $\begin{array}{l}\text { Life-threatening } \\
\text { consequences; } \\
\text { Urgent intervention indicated }\end{array}$ \\
\hline Radiation dermatitis & $\begin{array}{l}\text { Faint erythema or dry } \\
\text { desquamation. }\end{array}$ & $\begin{array}{l}\text { Moderate to brisk } \\
\text { erythema; patchy moist } \\
\text { desquamation, mostly } \\
\text { confined to skin folds } \\
\text { and creases; moderate } \\
\text { oedema }\end{array}$ & $\begin{array}{l}\text { Moist desquamation in areas } \\
\text { other than skin folds and } \\
\text { creases; bleeding induced by } \\
\text { minor trauma or abrasion }\end{array}$ & $\begin{array}{l}\text { Life-threatening } \\
\text { consequences; skin necrosis } \\
\text { or ulceration of full-thickness } \\
\text { dermis; } \\
\text { Spontaneous bleeding from } \\
\text { involved site; skin graft } \\
\text { indicated }\end{array}$ \\
\hline $\begin{array}{l}\text { Bio-radiation } \\
\text { dermatitis [27] }\end{array}$ & $\begin{array}{l}\text { Faint erythema or dry } \\
\text { desquamation; and } \\
\text { lesions due to } \\
\text { bio-treatment (e.g. } \\
\text { xerosis, papules, } \\
\text { pustules, and other } \\
\text { clinical signs), which } \\
\text { may or may not be } \\
\text { associated with } \\
\text { symptoms of pruritus or } \\
\text { tenderness. } \\
\text { No limiting } \\
\text { age-appropriate ADL. }\end{array}$ & $\begin{array}{l}\text { Moderate to brisk } \\
\text { erythema; patchy moist } \\
\text { desquamation in folds } \\
\text { and creases; lesions due } \\
\text { to bio-treatment (e.g. } \\
\text { crusts, papules, } \\
\text { pustules, and other } \\
\text { clinical signs) mostly } \\
\text { confined to less than } \\
\text { 50\% of radiated area; } \\
\text { bleeding lesions with } \\
\text { friction or trauma. } \\
\text { Limiting } \\
\text { age-appropriate } \\
\text { instrumental ADL. }\end{array}$ & $\begin{array}{l}\text { Moist desquamation in areas } \\
\text { other than skin folds and } \\
\text { creases; extensive ( }>50 \% \text { of } \\
\text { involved field) confluent } \\
\text { lesions due to bio-treatment } \\
\text { (e.g. crusts, papules, pustules, } \\
\text { and other clinical signs) } \\
\text { associated to bleeding by } \\
\text { minor trauma or abrasion. } \\
\text { Limiting selfcare. }\end{array}$ & $\begin{array}{l}\text { Life-threatening } \\
\text { consequences: skin necrosis } \\
\text { or ulceration of full thickness } \\
\text { dermis; } \\
\text { Extensive (>50\% of involved } \\
\text { field) confluent lesions due to } \\
\text { bio-treatment (e.g. crusts, } \\
\text { papules, pustules, and other } \\
\text { clinical signs) associated to } \\
\text { signs of spontaneous } \\
\text { bleeding. } \\
\text { Systemic inflammation } \\
\text { response syndrome (SIRS) }\end{array}$ \\
\hline
\end{tabular}

The skin integrity (including the presence of skin atrophy), body site (such as the neck skin where the epidermis is thin and subjected to friction from overlapping skin folds [23]), obesity [29], nutritional status, age, sun exposure, exposure to extreme temperatures, and smoking, are all factors that increase the risk of radiation-induced toxicity [30]. Race and ethnicity are also considered factors that may affect the skin response to RT [31,32].

Pre-existing inflammatory skin disease may favour the development of severe radiation dermatitis, although no formal studies have confirmed this hypothesis. In particular, atopic eczema, which very frequently affects the head and neck area, is associated with skin that is very sensitive to a variety of environmental factors including heat, solar radiation, detergents, and water. In addition, ionizing radiation may elicit or exacerbate autoimmune bullous disease such as pemphigus [33-35].

2. Co-morbidities (such as rheumatoid arthritis, lupus erythematosis, or scleroderma, etc.)

Pre-existing connective tissue or autoimmune diseases, including scleroderma, lupus erythematosis, and perhaps rheumatoid arthritis (RA), unpredictably predispose patients to the development of severe radiation dermatitis [36-39]. At any rate, the studies that support this statement are retrospective with small numbers of patients and use different scoring scales for complications. As a consequence, these factors may contribute to an overestimation of true radiation-induced morbidity, but the fact that peripheral lymphocytes from patients with lupus erythematosis, RA and systemic sclerosis have significantly greater DNA damage after irradiation than do those from control subjects $[40,41]$. It is in any case advisable to be prudent in particular when the connective tissue disease is active or associated to an uncontrolled hypertension and type I diabetes [42].

3. Diagnosis of gene repair disorders (for example Xeroderma pigmentosum, ataxia-telangiectasia, Fanconi anaemia, Nijmegen syndrome, etc.)

As ionizing radiation produces DNA damage, patients with impaired cellular DNA repair capabilities are at increased risk. Patients with ataxia-telangiectasia, a rare autosomal-recessive disorder resulting from mutations in both copies of the ATM gene, are predisposed to develop 
severe complications after RT. It is hypothesized that some patients who develop serious, unanticipated radiation dermatitis may be heterozygous for this mutated ATM gene (approximately $1 \%$ of the general population) [43,44].

Other rare diseases with reduced cellular DNA repair capability, such as hereditary nevoid basal cell carcinoma syndrome (Gorlin syndrome), Fanconi's anaemia, Bloom syndrome, Xeroderma pigmentosum, Nijmegen breakage syndrome [45], familial polyposis, Gardner's syndrome, hereditary malignant melanoma, dysplastic nevus syndrome, and DNA ligase IV deficiency [45-56], may expose patients to severe risks and either RT should be avoided altogether or the skin-doses should be selected with great care.

\subsubsection{Treatment-related factors}

1. Skin total dose, Fraction size, type and energy of radiation and the use of bolus

Treatment-related factors such as skin total dose, fraction size, type and energy of radiation can impact skin reactions: larger treatment volume, larger total dose of radiation, larger fraction size ( $>2$ Gy per fraction), and higher surface dose (bolused or low energy beams) can increase skin toxicity [5,57-60].

2. Chemotherapy or other medical photosensitizing concomitant therapies

Also chemotherapy or other medical radio-sensitizing or photosensitizing concomitant therapies may also increase acute toxicity to the skin $[3,7,61-65]$.

Radio-sensitizers are drugs that given either immediately before/during, or less than 7 days after radiation, cause increased cellular damage and impaired repair [62]. Paclitaxel or docetaxel when used in conjunction with RT produce synergistic cutaneous toxicity that is both schedule- and dosedependent [61].

Photosensitizers are drugs that are activated by UVA, UVB, and visible range beams and their photo-activated compounds damage the surrounding cutaneous tissue [65].

\subsection{Baseline assessment (successively, during CRT, at least weekly) and preventive recommendations}

\subsubsection{General recommendations}

1. A detailed medical history relating to personal and family risk factors should be carefully collected.

2. It is important to establish a proper technique to minimize the dose delivered to the skin [57,66-68].

In head and neck IMRT plans, high skin dose [67] is consequent to multiple tangential-to-skin beams and to the bolus effect of immobilization devices. Some Authors suggest excluding the skin over uninvolved neck nodes from target volumes in order to reduce the dose to the skin by $6-7 \%[57,69]$.

At any rate, every effort must be taken to avoid high doses to the skin. The use of advanced technologies for evaluating the skin dose might be considered $[70,71]$.
3. Avoid radio-sensitizing drugs during radiation treatment, if clinically indicated: when chemotherapy is not concurrent (paclitaxel, docetaxel), a period of almost seven days has to be respected (see point $2 \mathrm{~b} 2$ ).

4. Caution must be used with non-necessary common photosensitizing drugs and sun exposure during chemoradiation (see point $2 \mathrm{~b} 2$ ).

5. Patients must avoid smoking [72].

The dangerous effects of tobacco on irradiated skin [72], immune response [73], and repairing capacity of the tissue [74] are well known.

\subsubsection{Preventive hygienic recommendations}

1. Washing with lukewarm water and a mild soap $(\mathrm{pH}-$ neutral or non-alkaline soap) can be used as routine care for all patients receiving radiation therapy.

Washing with lukewarm water and a mild $\mathrm{pH}$-neutral or non-alkaline soap should not be restricted as routine care for patients receiving radiation therapy [75-78].

2. Shaving with a sharp, disposable multi-blade wet razor or with a non-traumatizing electric razor.

It is advisable to shave with a sharp, disinfected wet razor or with a non-traumatizing electric razor [26].

3. Avoid micro-traumas in irradiated area or tapes and adhesives.

Physical traumas, for example due to clothes, exposure to direct sunlight or exposure to extreme temperatures and the use of skin irritants such as alcohol-based lotions and perfumes should be avoided. This recommendation is particularly important if epidermal growth-factor receptor inhibitors are used [26].

4. Preventive non-steroidal treatments: A moisturizing cream based on urea or anionic polar phospholipid is advised. Trolamine and Aloe Vera are not recommended.

Many non-steroidal topical treatments or oral systemic therapies have been used in radio-dermatitis prevention. They have been used especially on breast skin, but it is generally believed that these results can be reported also for head-and-neck skin.

Oral preventive treatment

Oral systemic therapies such as zinc supplements [79], pentoxifylline [80], and Wobe-Mugos E (i.e. proteolytic enzymes containing $100 \mathrm{mg}$ papain, $40 \mathrm{mg}$ trypsin, and $40 \mathrm{mg}$ chymotrypsin that should provide anti-inflammatory and analgesic effects) [81-83] are not sufficiently supported by the literature results in radiodermatitis prophylaxis [84].

Non-steroidal preventive topical treatments

Lipiderm [85], vitamin C solution [86], chamomile cream [87], almond ointment [87], petroleum based ointment (Aquaphor) [88-90], hyaluronic acid [90-95], sucralfate and its derivatives [93,96-98], glutathione and anthocyanin (Raygel) [99], LED (light-emitting diode lasers) [100], Theta cream [101], and Dexpanthenol (a 
provitamin of B5) [91,101,102] did not demonstrate a sufficient benefit in terms of dermatitis prevention.

On the contrary, aloe vera [103-106] and trolamine $[85,88-90,107,108]$ are not recommended [84]. In particular aloe vera is not a moisturizer [109], thus it may be contraindicated in the case of xerosis.

Calendula is likely to be effective $[107,110]$ but it is difficult to apply [107] [84].

An anti-inflammatory drug from Chinese medicine (Lian Bai liquid) in a non-blinded trial of 126 participants [111] reported the effectiveness in preventing and treating radio-induced dermatitis. This drug needs confirming in further multicentre trials.

Silver sulfadiazine cream was shown to be active in preventing radio-dermatitis $[112,113]$, but its use as prophylactic management is not recommended because of concerns about sensitivity or resistance with overuse [109,114].

Finally, urea lotion [115,116], and anionic phospholipid-based cream [117] were shown to be more effective than the control arms that used conventional dry skin care and aloe vera gel respectively. Urea cream should be used only with a urea concentration of $5-10 \%$.

\section{Preventive dressing: barrier films}

Barrier films have been used in order to reduce trauma and retain moisture in the maintenance of intact skin during RT.

In a breast cancer study by Graham et al. [118], a spray-on no-sting barrier was evaluated as a prophylactic treatment in the prevention of moist desquamation (vs. glycerine cream) and it was associated with a lower total skin toxicity score $(p=0.005)$ and a lower prevalence of pruritus $(p=0.01)$. Successively, the same Authors, testing a moisturizing alcohol-free barrier film (MDBC), did not find any advantages vs. glycerine cream [119]. Dermofilm (a micro-thin emollient skin protector, containing hydrophilic and lipophilic agents) also was used and, although a symptomatic improvement occurred, a larger trial was advocated but never performed [120].

Safetac-based silicon dressings (Mepilex-Lite ${ }^{\circledR}$ dressings) provide mechanical protection from trauma, similarly to no-sting barriers, and showed a significant $30-40 \%$ decrease in skin reaction severity in breast cancer patients [121-123]. However, Mepilex-Lite dressings did not affect moist desquamation rates when used to manage existing skin reactions [123]. This failure was attributed by the Authors to the necessity to remove Mepilex-Lite dressings during radiation delivery because of their thickness and their bolus effect [122]. Thus, the same Authors used Mepitel Film (a thinner Safetac-based dressing) with a clinically insignificant bolus effect of $0.12 \mathrm{~mm}$ [124]. This film could be safely left on during radiation delivery and it was shown that it prevented the occurrence of radiation-induced moist desquamation and decreased the extent of skin reaction severity by $92 \%$. These dressings have never been used as a preventive tool in HNCPs where the irregularity of skin surface makes these devices difficult to be left in site (in the personal experience of one of the authors: R.E.).

Silver dressing (a non-adherent rayon and polyester material coated with nano-crystalline silver) does not seem to be useful as a preventive treatment [125].

5. It is not advisable to use cream or other skin products from 1 to $4 \mathrm{~h}$ before treatment so as to avoid "build-up" effects.

While the practice of avoiding the use of products on the skin from 1 to $4 \mathrm{~h}$ before treatment may have a theoretical foundation in order to avoid the so called "build-up" effect, no evidence exists to support this practice [126].

Topical Vitamin K1 in prophylactic or reactive treatment may reduce the incidence of grade- 3 toxicity and improve Cetuximab compliance. Indeed, Vitamin K activates EGFR signalling. Preclinical studies have shown that vitamin K3 completely abrogated EGFR inhibition in vitro and was associated with up-regulation of phosphorylated EGFRs in the skin when used in topically-applied cream $[127,128]$. Some clinical evidence has been presented on the beneficial effect of vitamin $\mathrm{K} 1 \mathrm{cream}$ on patients experiencing a severe antiEGFR-induced acne-like rash [129-132]. Yet, the panellists retain there is not sufficient evidence to recommend it in HNCPs and future prospective multicentre randomized trials are needed.

\subsubsection{Recommendations if risk factors are present.}

1. Maintain an optimal control of co-morbidities as diabetes and nutritional status; a close collaboration with the diabetologist and the dietician is needed.

2. If active signs/symptoms of rheumatoid arthritis, systemic lupus erythematosis, psoriatic arthritis, or scleroderma are diagnosed, consider using conventional fractionation, reducing total dose where possible, keeping treatment volumes as small as possible and keeping a high level of caution with multimodality treatments, especially when $\mathrm{RT}$ is associated to concurrent chemotherapy or biological anticancer treatments. A close liaison with the rheumatologist and dermatologist is needed.

3. If gene repair disorders are diagnosed (for example Xeroderma pigmentosum, ataxia-telangiectasia, Fanconi anaemia, Nijmegen syndrome, etc.) consider avoiding RT.

Particular attention is needed for those patients with active connective tissue disease and/or a combination of uncontrolled hypertension with type I diabetes [42].

Apparently healthy HNCPs, carrying heterozygote diseases with a reduced DNA-repairing capability in their family history, should be treated with prudently selected doses or, when possible, with a non-radiation oncological approach.

RT must be avoided in patients with Ataxia-telangiectasia or suffering from those diseases with a reduced cellular DNA repair capability (see point 2a3).

It is essential to evaluate the HNCP's skin prior to any treatment, especially those areas that will be irradiated. 
Every pre-existing skin disease, such as atopic eczema, acne, rosacea, ichthyosis, and psoriasis, must be documented, especially if using EGFRis [22].

\subsection{Topical steroidal agents}

1. 4.4a. The use of corticosteroid creams for treating itching or irritation should be limited over time as they can cause thinning of the skin and bacterial infections.

2. $4.4 \mathrm{~b}$. The use of corticosteroid creams in the prevention of skin reactions is not advisable as they can cause thinning of the skin and bacterial infections.

Corticosteroids have potent anti-inflammatory effects (such as vasoconstriction, reduced capillary permeability, and inhibition of leucocyte migration $[133,134]$ ) in many dermatological conditions, thus they have often been prescribed in both the prevention and management of radiation skin reactions.

The use of corticosteroid creams in the management or prevention of skin reactions has provided contrasting results [102,135-140]. However, this use must be limited over time because it can cause thinning of the skin and favour bacterial infections $[77,78,141,142]$. Current evidence is insufficient to support or refute this practice.

While topical glucocorticosteroid can help in the treatment of xerosis and reduce water loss from the skin in patients receiving panitumumab [143], there is no consensus regarding the efficacy of these agents on irradiated skin $[102,139]$. Moreover, some authors suggest that topical glucocorticoids may increase the cutaneous toxicity of EGFRis [127]. In any case, it is prudently advisable to limit the use of glucocorticosteroids to short periods of time (1-2 weeks) [22,26].

\subsection{Dressings and advanced medications}

1. Even though there is insufficient evidence to support a recommendation for using dressings or advanced medications, these can be used to protect irradiated skin from trauma or, in the case of wet desquamation, in order to control pain, bleeding, and exudates.

2. Protection of ulcerated parts can be provided with hydrocolloid films after having cleaned the skin. The ultrathin films can be maintained during radiation. This dressing should be removed when it is saturated with exudate.

3. Hydrofibers, calcium alginate dressings, and polyurethane or silicone foams could be used when the exudate is very abundant. No evidence exists to support one product over another.

4. When crusts or crustose exudations are present, the debridement of crusts may help to reduce the risk of super-infection and bleeding and may help with pain management

The use of hydrogel and hydrocolloid dressings has been reported in the case of moist desquamation. Hydrogel lacks supporting evidence of superior efficacy when tested against either gentian violet [144] or drying dressings [145]. Although hydrocolloid dressings do not seem to be advantageous in terms of healing time, they appear to be useful in terms of pain control in severe Cetuximab/RT dermal toxicity $[4,9]$.

Finally, in a small study, a silver-leaf dressing (effective for the prevention of radio-dermatitis in anal or gynaecological cancer patients [146]) was used on HNCP skin: no differences between the dressing and silver sulfadiazine cream in terms of severity of skin toxicity or healing was obtained, but pain control was improved using silver-leaf dressing [112].

\subsection{Infection management}

1. 4.6a. Consider topical or systemic antimicrobials if positive cultures or documented infections are present.

2. 4.6b. An empirical systemic antibiotic therapy must be used as soon as possible when two altered parameters of Systemic Inflammatory Response Syndrome (SIRS) and/or other signs of systemic inflammatory response to infection (such as inflammatory, haemodynamic, organ dysfunction and tissue perfusion parameters $[147,148]$ ) coexist with a suspected infection.

SIRS parameters need monitoring. Indeed, even if two positive SIRS parameters are not specific of sepsis [148-150], they may help physicians to graduate the urgency of intervention, to promptly activate the search for infection and for other signs of systemic inflammatory response to infection (such as inflammatory, haemodynamic, organ dysfunction and tissue perfusion parameters $[147,148])$, in order to shorten the time to start antibiotic administration [151].

In cases of dermatitis of grade $2 / 3$, when a superinfection is suspected without systemic-inflammatoryresponse involvement, antiseptics and/or topical antibiotics (such as clindamycin and erythromycin) may be helpful, but it might be useful to obtain an antibiogram of exudative lesions.

If serious toxicity is associated to a systemic inflammatory response, culture data should be obtained before starting any empirical antibiotic treatment [151].

\subsection{Serious toxicity and treatment interruption}

\subsubsection{Grade III toxicity}

- In the case of toxicity of grade III or less, every effort should be made in order not to avoid interrupting the radiation treatment.

\subsubsection{Grade IV toxicity}

1. Consider interrupting both systemic and radiation treatments. If the patient has been treated with Cetuximab and RT, Cetuximab should be interrupted until the skin reaction has resolved to at least grade II.

2. Refer patient for wound care or wound specialist management. 
Any interruption of radiation therapy may result in a decreased risk of local oncological control. Thus, in the presence of grade three toxicity the panel suggests continuing RT because the advantages consequent to local-toxicity recovering might be annulled by the negative effects of tumour re-growth $[152,153]$. Of course, the symptoms of local toxicity must be monitored/controlled and the panel suggests that HNCPs might be hospitalized in order that the specific antineoplastic treatments can continue safely by limiting interruption as much as possible.

In the case of Grade IV toxicity, the main cause of lifethreatening consequences is due to the systemic inflammation response to infection. Thus, the presence of grade IV and/or sepsis should induce the interruption of all systemic (CT or EGFRi) and local (RT) antineoplastic treatments.

\section{Considerations for the future}

Some novelties are coming out from the genetic and epigenetic research area. Patient populations having a genetic predisposition to radiation dermatitis could be identified $[154,155]$. Indeed, the object of on-going researches is some gene-clusters, not associated with other genetic diseases/abnormalities [156-158]. These gene-clusters may be present in "healthy" patients (meaning patients who are otherwise healthy beyond having a malignancy) and they might predict sensitivity to radiation. This area should deserve more attention because this strategy might have a big impact in the next future such as in other radiation toxicities (e.g. oral mucositis [159], skin toxicity [154,157]).

Furthermore, the "in-field" toxicity assessment tools need to be refined (CTCAE v 4.0 and bioradiation dermatitis) in light of the next imminent version of CTCAE.

On this purpose, the scientific community should wonder about the concern that the incorporation of ADL components in the scoring scales might result in more of a subjective assessment. This fact might result in a significant drift from the previous scoring scales that were based more on physical appearances of skin lesions. Indeed, the ADL components might further complicate the process of establishing effective treatments for dermatitis. In fact, the addition of the ADL may also be incorporating symptoms arising from more than one radiation toxicity. For example, when a patient is unable to get dressed it might be in consequence of the fact that either he could be physically limited in range of motion or it may be due to pain or to fatigue or to other standalone toxicities. All of these causes might be separate from the effects of dermatitis. These confounding problems could make it difficult to assess treatments for the dermatitis toxicity, specifically. Furthermore, pre-clinical research models, used to screen potential compounds, are designed to mirror clinical scoring scales. Consequently, ADL components could be beyond the physical appearances of dermatitis and this fact could make it more difficult to determine an efficacy signal for providing the appropriate treatment.
Finally, the biodermatitis scale, proposed by European experts and suggested in this consensus, needs validating in a clinical trial. The on-going Gortec 2014-02 trial (Personal communication) is a multinational project that has been prospectively evaluating the rate of severe dermatitis in patients receiving radiation plus Cetuximab for unresectable head and neck cancer. This prospective trial has also the aim to validate the bio-radiation dermatitis scale by comparing it to the assessment scale of NCI-CTC v 4.3.

\section{Conclusions}

Skin toxicity is a very common occurrence in integrated treatments for HNCPs, and it may result in pain, discomfort, irritation, itching and finally delays or interruptions of antineoplastic treatments, influencing the prognosis of potentially curable tumours. Many studies have been conducted, but there are many uncertainties. As a consequence, clinical management varies from centre to centre.

Our review aimed to obtain some indications for the management of skin toxicity in those situations where evidence is poor and it further tried to draw up recommendations/suggestions for HNCPs based on the consensus among multidisciplinary health professionals. The adopted Delphi strategy provides a highly structured and transparent process to obtain anonymous feedback. The authors believe that this approach, with the support of external experts in this field, allowed participants to give recommendations more safely in those situation where it is necessary to act without the support of strong evidence.

The main aim is to standardize diagnostic and treatment behaviour among centres participating in multicentre trials.

Clearly, the main limit of this study is the fact that part of the evidence is obtained from non-HNCP literature, and many studies are small and/or retrospective.

In the future, an increased understanding of the mechanisms of cellular damage may lead to a better prevention of this toxicity.

Acute in-field skin toxicity management in head and neck cancer patients treated with radiotherapy and chemotherapy or EGFR inhibitors: literature review and consensus

\section{Conflict of interest}

The Authors have no financial and personal relationships with other people or organizations that could inappropriately influence (bias) this work.

\section{Funding}

This study was partly supported by Lega Tumori sezione di Cuneo. 


\section{Acknowledgments}

Alterio Daniela (Milan), Azzarello Giuseppe (Padova), Bolner Andrea (Trento), Ciotti Ombretta (Varese), Corvò Renzo (Genova), Fiscella Michela (Milan), Gavazzi Cecilia (Milan), Grisanti Salvatore (Brescia), Mario Grosso (Turin), Magrini Stefano (Brescia), Maurizi Enrici Riccardo (Rome), Orlandi Ester (Milano), Paiar Fabiola (Firenze), Pavanato Giovanni (Rovigo), Pizzorni Nicole (Milano), Ripamonti Carla (Milan), Salgarello Stefano (Brescia), Giuseppe Sanguineti (Rome).

\section{References}

[1] Pignon J-P, Maître Ale, Maillard E, Bourhis J. Meta-analysis of chemotherapy in head and neck cancer (MACH-NC): an update on 93 randomised trials and 17,346 patients. Radiother Oncol 2009;92:4-14, http://dx.doi.org/10.1016/j.radonc.2009.04.014.

[2] Noble-Adams R. Radiation-induced reactions. 1: an examination of the phenomenon. Br J Nurs Mark Allen Publ 1999;8:1134-40.

[3] Merlano M, Russi E, Benasso M, et al. Cisplatin-based chemoradiation plus Cetuximab in locally advanced head and neck cancer: a phase II clinical study. Ann Oncol Off J Eur Soc Med Oncol ESMO 2011;22:712-7, http://dx.doi.org/10.1093/annonc/mdq412.

[4] Russi EG, Merlano MC, Numico G, et al. The effects on pain and activity of daily living caused by crusted exudation in patients with head and neck cancer treated with Cetuximab and radiotherapy. Support Care Cancer Off J Multinatl Assoc Support Care Cancer 2012;20:2141-7, http://dx.doi.org/10.1007/s00520-011-1324-4.

[5] Porock D. Factors influencing the severity of radiation skin and oral mucosal reactions: development of a conceptual framework. Eur J Cancer Care (Engl) 2002;11:33-43.

[6] Bentzen SM, Saunders MI, Dische S, Bond SJ. Radiotherapy-related early morbidity in head and neck cancer: quantitative clinical radiobiology as deduced from the CHART trial. Radiother Oncol 2001;60:123-35, http://dx.doi.org/10.1016/S0167-8140(01)00358-9.

[7] Wong ASC, Soo RA, Lu JJ, et al. Paclitaxel, 5-fluorouracil and hydroxyurea concurrent with radiation in locally advanced nasopharyngeal carcinoma. Ann Oncol 2006;17:1152-7, http://dx.doi.org/10.1093/annonc/md1090.

[8] Pryor DI, Porceddu SV, Burmeister BH, et al. Enhanced toxicity with concurrent Cetuximab and radiotherapy in head and neck cancer. Radiother Oncol 2009;90:172-6, http://dx.doi.org/10.1016/j.radonc.2008.09.018.

[9] Russi EG, Merlano MC, Comino A, Numico G. Ultrathin Hydrocolloid Dressing in Skin Damaged From Alternating Radiotherapy and Chemotherapy Plus Cetuximab in Advanced Head and Neck Cancer (G.O.N.O. AlteRCC Italian Trial): In Regard to Macmillan et al. (Int J Radiat Oncol Biol Phys 2007; 68:864-872). Int J Radiat Oncol 2007;69:638-9, http://dx.doi.org/10.1016/j.ijrobp.2007.05.063.

[10] Russi EG, Raber-Durlacher JE, Sonis ST. Local and systemic pathogenesis and consequences of regimen-induced inflammatory responses in patients with head and neck cancer receiving chemoradiation. Mediators Inflamm 2014:2014, http://dx.doi.org/10.1155/2014/518261.

[11] Eilers RE, Gandhi M, Patel JD, et al. Dermatologic infections in cancer patients treated with epidermal growth factor receptor inhibitor therapy. J Natl Cancer Inst 2010;102:47-53, http://dx.doi.org/10.1093/jnci/djp439.

[12] D'haese S, Van Roy M, Bate T, Bijdekerke P, Vinh-Hung V. Management of skin reactions during radiotherapy in Flanders
(Belgium): a study of nursing practice before and after the introduction of a skin care protocol. Eur J Oncol Nurs 2010;14:367-72, http://dx.doi.org/10.1016/j.ejon.2009.10.006.

[13] Loblaw DA, Prestrud AA, Somerfield MR, et al. American Society of Clinical Oncology Clinical Practice Guidelines: formal systematic review-based consensus methodology. J Clin Oncol 2012;30:3136-40, http://dx.doi.org/10.1200/JCO.2012.42.0489.

[14] Noble-Adams R. Radiation-induced skin reactions. 3: Evaluating the RISRAS. Br J Nurs Mark Allen Publ 1999;8:1305-12.

[15] Noble-Adams R. Radiation-induced skin reactions. 2: Development of a measurement tool. Br J Nurs Mark Allen Publ 1999;8:1208-11.

[16] Atherton PJ, Burger KN, Loprinzi CL, et al. Using the Skindex-16 and Common Terminology Criteria for Adverse Events to assess rash symptoms: results of a pooled-analysis (N0993). Support Care Cancer 2011, http://dx.doi.org/10.1007/s00520-011-1266-x.

[17] Cox JD, Stetz J, Pajak TF. Toxicity criteria of the Radiation Therapy Oncology Group (RTOG) and the European organization for research and treatment of cancer (EORTC). Int J Radiat Oncol 1995;31:1341-6, http://dx.doi.org/10.1016/0360-3016(95)00060-C.

[18] CTCAE Panel. Common Terminology Criteria for Adverse Events v3.0 (CTCAE). US Department Health Hum Serv Natl Inst Health Natl Cancer Inst; 2006. http://www.zotero.org/support/quick_start_guide_ [accessed 06.25.10].

[19] National Cancer Institute. Common Terminology Criteria for Adverse Events v. 4.0; 2009.

[20] Berthelet E, Truong PT, Musso K, et al. Preliminary reliability and validity testing of a new Skin Toxicity Assessment Tool (STAT) in breast cancer patients undergoing radiotherapy. Am J Clin Oncol 2004;27:626-31

[21] Chen AP, Setser A, Anadkat MJ, et al. Grading dermatologic adverse events of cancer treatments: the Common Terminology Criteria for Adverse Events Version 4.0. J Am Acad Dermatol 2012;67:1025-39, http://dx.doi.org/10.1016/j.jaad.2012.02.010.

[22] Pinto C, Barone CA, Girolomoni G, et al. Management of skin toxicity associated with Cetuximab treatment in combination with chemotherapy or radiotherapy. Oncologist 2011;16:228-38, http://dx.doi.org/10.1634/theoncologist.2010-0298.

[23] Bernier J, Bonner J, Vermorken JB, et al. Consensus guidelines for the management of radiation dermatitis and coexisting acne-like rash in patients receiving radiotherapy plus EGFR inhibitors for the treatment of squamous cell carcinoma of the head and neck. Ann Oncol 2008;19:142-9, http://dx.doi.org/10.1093/annonc/mdm400.

[24] Balagula Y, Garbe C, Myskowski PL, et al. Clinical presentation and management of dermatological toxicities of epidermal growth factor receptor inhibitors. Int J Dermatol 2011;50:129-46, http://dx.doi.org/10.1111/j.1365-4632.2010.04791.x.

[25] Lacouture ME, Maitland ML, Segaert S, et al. A proposed EGFR inhibitor dermatologic adverse event-specific grading scale from the MASCC skin toxicity study group. Support Care Cancer Off J Multinatl Assoc Support Care Cancer 2010;18:509-22, http://dx.doi.org/10.1007/s00520-009-0744-x.

[26] Bernier J, Russi EG, Homey B, et al. Management of radiation dermatitis in patients receiving Cetuximab and radiotherapy for locally advanced squamous cell carcinoma of the head and neck: proposals for a revised grading system and consensus management guidelines. Ann Oncol Off J Eur Soc Med Oncol ESMO 2011;22:2191-200, http://dx.doi.org/10.1093/annonc/mdr139.

[27] Russi EG, Bensadoun R-J, Merlano MC, et al. Bio-radiation dermatitis: the need of a new grading: in regard to Bernier et al: Ann Oncol 2011; 22 (10): 2191-2200. Ann Oncol Off J Eur Soc Med Oncol ESMO 2013;24:2463-5, http://dx.doi.org/10.1093/annonc/mdt281.

[28] Langendijk JA, Oosting SF. Grading system and management guidelines for dermatitis induced by head and neck radiotherapy plus Cetuximab: clinical validation required. Ann Oncol 2011;22:2157-9, http://dx.doi.org/10.1093/annonc/mdr410. 
[29] Twardella D, Popanda O, Helmbold I, et al. Personal characteristics, therapy modalities and individual DNA repair capacity as predictive factors of acute skin toxicity in an unselected cohort of breast cancer patients receiving radiotherapy. Radiother Oncol J Eur Soc Ther Radiol Oncol 2003;69:145-53.

[30] Hymes SR, Strom EA, Fife C. Radiation dermatitis: clinical presentation, pathophysiology, and treatment 2006. J Am Acad Dermatol 2006;54:28-46, http://dx.doi.org/10.1016/j.jaad.2005.08.054.

[31] Gewandter JS, Walker J, Heckler CE, Morrow GR, Ryan JL. Characterization of skin reactions and pain reported by patients receiving radiation therapy for cancer at different sites. J Support Oncol 2013;11:183-9.

[32] Ryan JL, Bole C, Hickok JT, et al. Post-treatment skin reactions reported by cancer patients differ by race, not by treatment or expectations. $\mathrm{Br} \mathrm{J}$ Cancer 2007;97:14-21, http://dx.doi.org/10.1038/sj.bjc.6603842.

[33] Girolomoni G, Mazzone E, Zambruno G. Pemphigus vulgaris following cobalt therapy for bronchial carcinoma. Dermatologica 1989;178:37-8.

[34] Vigna-Taglianti R, Russi EG, Denaro N, Numico G, Brizio R. Radiation-induced pemphigus vulgaris of the breast. Cancer Radiothér J Société Fr Radiothér Oncol 2011;15:334-7, http://dx.doi.org/10.1016/j.canrad.2011.01.006.

[35] Ruocco V, Ruocco E, Lo Schiavo A, Brunetti G, Guerrera LP, Wolf R. Pemphigus: etiology, pathogenesis, and inducing or triggering factors: facts and controversies. Clin Dermatol 2013;31:374-81, http://dx.doi.org/10.1016/j.clindermatol.2013.01.004.

[36] Ross JG, Hussey DH, Mayr NA, Davis CS. Acute and late reactions to radiation therapy in patients with collagen vascular diseases. Cancer 1993; 71:3744-52.

[37] Morris MM, Powell SN. Irradiation in the setting of collagen vascular disease: acute and late complications. J Clin Oncol Off J Am Soc Clin Oncol 1997; 15:2728-35.

[38] Phan C, Mindrum M, Silverman C, Paris K, Spanos W. Matchedcontrol retrospective study of the acute and late complications in patients with collagen vascular diseases treated with radiation therapy. Cancer J Sudbury Mass 2003;9:461-6.

[39] Lin A, Abu-Isa E, Griffith KA, Ben-Josef E. Toxicity of radiotherapy in patients with collagen vascular disease. Cancer 2008;113:648-53, http://dx.doi.org/10.1002/cncr.23591.

[40] McCurdy D, Tai LQ, Frias S, Wang Z. Delayed repair of DNA damage by ionizing radiation in cells from patients with juvenile systemic lupus erythematosus and rheumatoid arthritis. Radiat Res 1997; 147:48-54

[41] Harris G, Cramp WA, Edwards JC, et al. Radiosensitivity of peripheral blood lymphocytes in autoimmune disease. Int J Radiat Biol Relat Stud Phys Chem Med 1985;47: 689-99.

[42] Chon BH, Loeffler JS. The effect of nonmalignant systemic disease on tolerance to radiation therapy. Oncologist 2002;7:136-43, http://dx.doi.org/10.1634/theoncologist.7-2-136.

[43] Bremer M, Klöpper K, Yamini P, Bendix-Waltes R, Dörk T, Karstens JH. Clinical radiosensitivity in breast cancer patients carrying pathogenic ATM gene mutations: no observation of increased radiation-induced acute or late effects. Radiother Oncol 2003;69:155-60, http://dx.doi.org/10.1016/j.radonc.2003.08.004.

[44] Iannuzzi CM, Atencio DP, Green S, Stock RG, Rosenstein BS. ATM mutations in female breast cancer patients predict for an increase in radiation-induced late effects. Int J Radiat Oncol Biol Phys 2002;52:606-13.

[45] Bakhshi S, Cerosaletti KM, Concannon P, et al. Medulloblastoma with adverse reaction to radiation therapy in Nijmegen breakage syndrome. J Pediatr Hematol Oncol 2003;25:248-51.

[46] Pollard JM, Gatti RA. Clinical radiation sensitivity with DNA repair disorders: an overview. Int J Radiat Oncol 2009;74:1323-31, http://dx.doi.org/10.1016/j.ijrobp.2009.02.057.
[47] Tucker SL, Turesson I, Thames HD. Evidence for individual differences in the radiosensitivity of human skin. Eur J Cancer Oxf Engl 1992;1990(28A):1783-91.

[48] Sanford KK, Tarone RE, Parshad R, Tucker MA, Greene MH, Jones GM. Hypersensitivity to G2 chromatid radiation damage in familial dysplastic naevus syndrome. Lancet 1987;2:1111-6.

[49] Sanford KK, Parshad R, Price FM, Tarone RE, Thompson J, Guerry D. Radiation-induced chromatid breaks and DNA repair in blood lymphocytes of patients with dysplastic nevi and/or cutaneous melanoma. J Invest Dermatol 1997;109:546-9.

[50] O'Driscoll M, Cerosaletti KM, Girard P-M, et al. DNA Ligase IV mutations identified in patients exhibiting developmental delay and immunodeficiency. Mol Cell 2001;8:1175-85, http://dx.doi.org/10.1016/S1097-2765(01)00408-7.

[51] Plowman PN, Bridges BA, Arlett CF, Hinney A, Kingston JE. An instance of clinical radiation morbidity and cellular radiosensitivity, not associated with ataxia-telangiectasia. Br J Radiol 1990;63:624-8.

[52] Hahn H, Wojnowski L, Zimmer AM, Hall J, Miller G, Zimmer A. Rhabdomyosarcomas and radiation hypersensitivity in a mouse model of Gorlin syndrome. Nat Med 1998;4:619-22.

[53] Dezawa M, Fujii K, Kita K, et al. Increase in nucleoli after X-radiation of fibroblasts of patients with Gorlin syndrome. J Lab Clin Med 1999;134:585-91.

[54] Hahn H, Wicking C, Zaphiropoulous PG, et al. Mutations of the human homolog of Drosophila patched in the nevoid basal cell carcinoma syndrome. Cell 1996;85:841-51.

[55] Johnson RL, Rothman AL, Xie J, et al. Human homolog of patched, a candidate gene for the basal cell nevus syndrome. Science 1996;272:1668-71

[56] Bremer M, Schindler D, Groß M, Dörk T, Morlot S, Karstens JH. Fanconi's anemia and clinical radiosensitivity. Strahlenther Onkol 2003;179:748-53, http://dx.doi.org/10.1007/s00066-003-1099-8.

[57] Lee N, Chuang C, Quivey JM, et al. Skin toxicity due to intensity-modulated radiotherapy for head-andneck carcinoma. Int J Radiat Oncol 2002;53:630-7, http://dx.doi.org/10.1016/S0360-3016(02)02756-6.

[58] Emami B, Lyman J, Brown A, et al. Tolerance of normal tissue to therapeutic irradiation. Int J Radiat Oncol Biol Phys 1991;21:109-22.

[59] Fernando IN, Ford HT, Powles TJ, et al. Factors affecting acute skin toxicity in patients having breast irradiation after conservative surgery: a prospective study of treatment practice at the Royal Marsden Hospital. Clin Oncol R Coll Radiol G B 1996;8:226-33.

[60] Hopewell JW, Nyman J, Turesson I. Time factor for acute tissue reactions following fractionated irradiation: a balance between repopulation and enhanced radiosensitivity. Int $\mathrm{J}$ Radiat Biol 2003;79:513-24.

[61] Bentzen SM, Overgaard M, Thames HD, Christensen JJ, Overgaard J. Early and late normal-tissue injury after postmastectomy radiotherapy alone or combined with chemotherapy. Int J Radiat Biol 1989;56:711-5.

[62] Shewach DS, Lawrence TS. Antimetabolite radiosensitizers. J Clin Oncol 2007;25:4043-50, http://dx.doi.org/10.1200/JCO.2007.11.5287.

[63] Wardman P. Chemical radiosensitizers for use in radiotherapy. Clin Oncol 2007;19:397-417, http://dx.doi.org/10.1016/j.clon.2007.03.010.

[64] Yang W, Read PW, Mi J, et al. Semiconductor nanoparticles as energy mediators for photosensitizer-enhanced radiotherapy. Int J Radiat Oncol 2008;72:633-5, http://dx.doi.org/10.1016/j.ijrobp.2008.06.1916.

[65] Onoue S, Seto Y, Gandy G, Yamada S. Drug-induced phototoxicity; an early in vitro identification of phototoxic potential of new drug entities in drug discovery and development. Curr Drug Saf 2009;4: 123-36.

[66] Nguyen TB, Hoole ACF, Burnet NG, Thomas SJ. The optimization of intensity modulated radiotherapy in cases where the planning 
target volume extends into the build-up region. Phys Med Biol 2009;54:2511-25, http://dx.doi.org/10.1088/0031-9155/54/8/017.

[67] Higgins PD, Han EY, Yuan JL, Hui S, Lee CK. Evaluation of surface and superficial dose for head and neck treatments using conventional or intensity-modulated techniques. Phys Med Biol 2007;52:1135-46, http://dx.doi.org/10.1088/0031-9155/52/4/018.

[68] Freedman GM, Anderson PR, Li J, et al. Intensity modulated radiation therapy (IMRT) decreases acute skin toxicity for women receiving radiation for breast cancer. Am J Clin Oncol 2006;29:66-70, http://dx.doi.org/10.1097/01.coc.0000197661.09628.03.

[69] Thomas SJ, Hoole ACF. The effect of optimization on surface dose in intensity modulated radiotherapy (IMRT). Phys Med Biol 2004;49:4919-28, http://dx.doi.org/10.1088/0031-9155/49/21/005.

[70] Roland TF, Stathakis S, Ramer R, Papanikolaou N. Measurement and comparison of skin dose for prostate and head-and-neck patients treated on various IMRT delivery systems. Appl Radiat Isot 2008;66:1844-9, http://dx.doi.org/10.1016/j.apradiso.2008.05.003.

[71] Kinhikar RA, Murthy V, Goel V, Tambe CM, Dhote DS, Deshpande DD. Skin dose measurements using MOSFET and TLD for head and neck patients treated with tomotherapy. Appl Radiat Isot 2009;67:1683-5, http://dx.doi.org/10.1016/j.apradiso.2009.03.008.

[72] Kraus-Tiefenbacher U, Sfintizky A, Welzel G, et al. Factors of influence on acute skin toxicity of breast cancer patients treated with standard three-dimensional conformal radiotherapy (3D-CRT) after breast conserving surgery (BCS). Radiat Oncol Lond Engl 2012;7:217, http://dx.doi.org/10.1186/1748-717X-7-217.

[73] McMaster SK, Paul-Clark MJ, Walters M, et al. Cigarette smoke inhibits macrophage sensing of Gram-negative bacteria and lipopolysaccharide: relative roles of nicotine and oxidant stress. Br J Pharmacol 2008;153:536-43, http://dx.doi.org/10.1038/sj.bjp.0707595.

[74] Xanthoulea S, Deliaert A, Romano A, Rensen SS, Buurman WA, van der Hulst RRWJ. Nicotine effect on inflammatory and growth factor responses in murine cutaneous wound healing. Int Immunopharmacol 2013;17:1155-64, http://dx.doi.org/10.1016/j.intimp.2013.10.022.

[75] Roy I, Fortin A, Larochelle M. The impact of skin washing with water and soap during breast irradiation: a randomized study. Radiother Oncol J Eur Soc Ther Radiol Oncol 2001;58:333-9.

[76] Campbell IR, Illingworth MH. Can patients wash during radiotherapy to the breast or chest wall? A randomized controlled trial. Clin Oncol R Coll Radiol G B 1992;4:78-82.

[77] Bolderston A, Lloyd NS, Wong RKS, Holden L, Robb-Blenderman L. Supportive Care Guidelines Group of Cancer Care Ontario Program in Evidence-Based Care. The prevention and management of acute skin reactions related to radiation therapy: a systematic review and practice guideline. Support Care Cancer Off J Multinatl Assoc Support Care Cancer 2006;14:802-17, http://dx.doi.org/10.1007/s00520-006-0063-4.

[78] Butcher K, Williamson K. Management of erythema and skin preservation; advice for patients receiving radical radiotherapy to the breast: a systematic literature review. J Radiother Pract 2012;11:44-54, http://dx.doi.org/10.1017/S1460396910000488.

[79] Lin L-C, Que J, Lin L-K, Lin F-C. Zinc supplementation to improve mucositis and dermatitis in patients after radiotherapy for head-andneck cancers: a double-blind, randomized study. Int J Radiat Oncol 2006;65:745-50, http://dx.doi.org/10.1016/j.ijrobp.2006.01.015.

[80] Aygenc E, Celikkanat S, Kaymakci M, Aksaray F, Ozdem C. Prophylactic effect of pentoxifylline on radiotherapy complications: a clinical study. Otolaryngol Head Neck Surg Off J Am Acad Otolaryngol Head Neck Surg 2004;130:351-6, http://dx.doi.org/10.1016/j.otohns.2003.08.015.

[81] Dale PS, Tamhankar CP, George D, Daftary GV. Co-medication with hydrolytic enzymes in radiation therapy of uterine cervix: evidence of the reduction of acute side effects. Cancer Chemother Pharmacol 2001;47(Suppl):S29-34.

[82] Gujral MS, Patnaik PM, Kaul R, et al. Efficacy of hydrolytic enzymes in preventing radiation therapy-induced side effects in patients with head and neck cancers. Cancer Chemother Pharmacol 2001;47(Suppl):S23-8.

[83] Kaul R, Mishra BK, Sutradar P, Choudhary V, Gujral MS. The role of Wobe-Mugos in reducing acute sequele of radiation in head and neck cancers - a clinical phase-III randomized trial. Indian J Cancer 1999;36:141-8.

[84] Wong RKS, Bensadoun R-J, Boers-Doets CB, et al. Clinical practice guidelines for the prevention and treatment of acute and late radiation reactions from the MASCC Skin Toxicity Study Group. Support Care Cancer Off J Multinatl Assoc Support Care Cancer 2013;21:2933-48, http://dx.doi.org/10.1007/s00520-013-1896-2.

[85] Fenig E, Brenner B, Katz A, et al. Topical Biafine and Lipiderm for the prevention of radiation dermatitis: a randomized prospective trial. Oncol Rep 2001;8:305-9.

[86] Halperin EC, Gaspar L, George S, Darr D, Pinnell S. A doubleblind, randomized, prospective trial to evaluate topical vitamin $\mathrm{C}$ solution for the prevention of radiation dermatitis. Int J Radiat Oncol 1993;26:413-6, http://dx.doi.org/10.1016/0360-3016(93)90958-X.

[87] Maiche AG, Gröhn P, Mäki-Hokkonen H. Effect of chamomile cream and almond ointment on acute radiation skin reaction. Acta Oncol Stockh Swed 1991;30:395-6.

[88] Fisher J, Scott C, Stevens R, et al. Randomized phase III study comparing best supportive care to Biafine as a prophylactic agent for radiation-induced skin toxicity for women undergoing breast irradiation: radiation therapy oncology group (RTOG) 97-13. Int J Radiat Oncol Biol Phys 2000;48:1307-10.

[89] Gosselin TK, Schneider SM, Plambeck MA, Rowe K. A prospective randomized, placebo-controlled skin care study in women diagnosed with breast cancer undergoing radiation therapy. Oncol Nurs Forum 2010;37:619-26, http://dx.doi.org/10.1188/10.ONF.619-626.

[90] Elliott EA, Wright JR, Swann RS, et al. Phase III trial of an emulsion containing trolamine for the prevention of radiation dermatitis in patients with advanced squamous cell carcinoma of the head and neck: results of radiation therapy oncology group trial 99-13. J Clin Oncol 2006;24:2092-7, http://dx.doi.org/10.1200/JCO.2005.04.9148.

[91] Løkkevik E, Skovlund E, Reitan JB, Hannisdal E, Tanum G. Skin treatment with bepanthen cream versus no cream during radiotherapy - a randomized controlled trial. Acta Oncol Stockh Swed 1996;35:1021-6.

[92] Liguori V, Guillemin C, Pesce GF, Mirimanoff RO, Bernier J. Double-blind, randomized clinical study comparing hyaluronic acid cream to placebo in patients treated with radiotherapy. Radiother Oncol 1997;42:155-61, http://dx.doi.org/10.1016/S0167-8140(96)01882-8.

[93] Primavera G, Carrera M, Berardesca E, Pinnaró P, Messina M, Arcangeli G. A double-blind, vehicle-controlled clinical study to evaluate the efficacy of MAS065D (XClair), a hyaluronic acid-based formulation, in the management of radiation-induced dermatitis. Cutan Ocul Toxicol 2006;25:165-71, http://dx.doi.org/10.1080/15569520600860009.

[94] Leonardi MC, Gariboldi S, Ivaldi GB, et al. A double-blind, randomised, vehicle-controlled clinical study to evaluate the efficacy of MAS065D in limiting the effects of radiation on the skin: interim analysis. Eur J Dermatol EJD 2008;18:317-21, http://dx.doi.org/10.1684/ejd.2008.0396.

[95] Kirova YM, Fromantin I, De Rycke Y, et al. Can we decrease the skin reaction in breast cancer patients using hyaluronic acid during radiation therapy? Results of phase III randomised trial. Radiother Oncol J Eur Soc Ther Radiol Oncol 2011;100:205-9, http://dx.doi.org/10.1016/j.radonc.2011.05.014.

[96] Maiche A, Isokangas OP, Gröhn P. Skin protection by sucralfate cream during electron beam therapy. Acta Oncol Stockh Swed 1994:33:201-3

[97] Evensen JF, Bjordal K, Jacobsen AB, Løkkevik E, Tausjø JE. Effects of Na-sucrose octasulfate on skin and mucosa reactions during radiotherapy of head and neck cancers - a randomized prospective study. Acta Oncol Stockh Swed 2001;40:751-5. 
[98] Wells M, Macmillan M, Raab G, et al. Does aqueous or sucralfate cream affect the severity of erythematous radiation skin reactions? A randomised controlled trial. Radiother Oncol J Eur Soc Ther Radiol Oncol 2004;73:153-62, http://dx.doi.org/10.1016/j.radonc.2004.07.032.

[99] Miko Enomoto T, Johnson T, Peterson N, Homer L, Walts D, Johnson N. Combination glutathione and anthocyanins as an alternative for skin care during external-beam radiation. Am J Surg 2005;189:627-31, http://dx.doi.org/10.1016/j.amjsurg.2005.02.001.

[100] Fife D, Rayhan DJ, Behnam S, et al. A randomized, controlled, double-blind study of light emitting diode photomodulation for the prevention of radiation dermatitis in patients with breast cancer. Dermatol Surg Off Publ Am Soc Dermatol Surg Al 2010;36:1921-7, http://dx.doi.org/10.1111/j.1524-4725.2010.01801.x.

[101] Röper B, Kaisig D, Auer F, Mergen E, Molls M. ThêtaCream $^{\circledR}$ versus Bepanthol ${ }^{\circledR}$ lotion in breast cancer patients under radiotherapy. Strahlenther Onkol 2004;180:315-22, http://dx.doi.org/10.1007/s00066-004-1174-9.

[102] Schmuth M, Wimmer Ma, Hofer S, et al. Topical corticosteroid therapy for acute radiation dermatitis: a prospective, randomized, double-blind study. Br J Dermatol 2002;146:983-91, http://dx.doi.org/10.1046/j.1365-2133.2002.04751.x.

[103] Williams MS, Burk M, Loprinzi CL, et al. Phase III double-blind evaluation of an aloe vera gel as a prophylactic agent for radiationinduced skin toxicity. Int J Radiat Oncol Biol Phys 1996;36:345-9.

[104] Olsen DL, Raub W, Bradley C, et al. The effect of aloe vera gel/mild soap versus mild soap alone in preventing skin reactions in patients undergoing radiation therapy. Oncol Nurs Forum 2001;28:543-7.

[105] Heggie S, Bryant GP, Tripcony L, et al. A phase III study on the efficacy of topical aloe vera gel on irradiated breast tissue. Cancer Nurs 2002;25:442-51.

[106] Richardson J, Smith JE, McIntyre M, Thomas R, Pilkington K. Aloe vera for preventing radiation-induced skin reactions: a systematic literature review. Clin Oncol R Coll Radiol G B 2005;17: 478-84.

[107] Pommier P, Gomez F, Sunyach MP, D'Hombres A, Carrie C, Montbarbon X. Phase III randomized trial of Calendula Officinalis compared with trolamine for the prevention of acute dermatitis during irradiation for breast cancer. J Clin Oncol 2004;22:1447-53, http://dx.doi.org/10.1200/JCO.2004.07.063.

[108] Abbas H, Bensadoun R-J. Trolamine emulsion for the prevention of radiation dermatitis in patients with squamous cell carcinoma of the head and neck. Support Care Cancer Off J Multinatl Assoc Support Care Cancer 2012;20:185-90, http://dx.doi.org/10.1007/s00520-011-1110-3.

[109] McQuestion M. Evidence-based skin care management in radiation therapy: clinical update. Semin Oncol Nurs 2011;27:e1-17, http://dx.doi.org/10.1016/j.soncn.2011.02.009.

[110] Feight D, Baney T, Bruce S, McQuestion M. Putting evidence into practice. Clin J Oncol Nurs 2011;15:481-92, http://dx.doi.org/10.1188/11.CJON.481-492.

[111] Ma H, Zhang X, Bai M, Wang X. Clinical effects of lianbai liquid in prevention and treatment of dermal injury caused by radiotherapy. J Tradit Chin Med Chung Tsa Chih Ying Wen Pan Spons -China Assoc Tradit Chin Med Acad Tradit Chin Med 2007;27: 193-6.

[112] Vavassis P, Gelinas M, Chabot Tr J, Nguyen-Tân PF. Phase 2 study of silver leaf dressing for treatment of radiation-induced dermatitis in patients receiving radiotherapy to the head and neck. J Otolaryngol - Head Neck Surg J Oto-Rhino-Laryngol Chir CervicoFaciale 2008;37:124-9.

[113] Hemati S, Asnaashari O, Sarvizadeh M, et al. Topical silver sulfadiazine for the prevention of acute dermatitis during irradiation for breast cancer. Support Care Cancer Off J Multinatl Assoc Support Care Cancer 2012;20:1613-8, http://dx.doi.org/10.1007/s00520-011-1250-5.
[114] Korinko A, Yurick A. Maintaining skin integrity during radiation therapy. Am J Nurs 1997;97:40-4.

[115] Momm F, Weissenberger C, Bartelt S, Henke M. Moist skin care can diminish acute radiation-induced skin toxicity. Strahlenther Onkol Organ Dtsch Röntgenges Al 2003;179:708-12, http://dx.doi.org/10.1007/s00066-003-1142-9.

[116] Pardo Masferrer J, Murcia Mejía M, Vidal Fernández M, et al. Prophylaxis with a cream containing urea reduces the incidence and severity of radio-induced dermatitis. Clin Transl Oncol Off Publ Fed Span Oncol Soc Natl Cancer Inst Mex 2010;12:43-8, http://dx.doi.org/10.1007/s12094-010-0465-0.

[117] Merchant TE, Bosley C, Smith J, et al. A phase III trial comparing an anionic phospholipid-based cream and aloe vera-based gel in the prevention of radiation dermatitis in pediatric patients. Radiat Oncol 2007;2:45, http://dx.doi.org/10.1186/1748-717X-2-45.

[118] Graham P, Browne L, Capp A, et al. Randomized, paired comparison of no-sting barrier film versus sorbolene cream (10\% glycerine) skin care during postmastectomy irradiation. Int $\mathrm{J}$ Radiat Oncol 2004;58:241-6, http://dx.doi.org/10.1016/S0360-3016(03)01431-7.

[119] Graham PH, Plant N, Graham JL, et al. A paired, doubleblind, randomized comparison of a moisturizing durable barrier cream to $10 \%$ glycerine cream in the prophylactic management of postmastectomy irradiation skin care: Trans Tasman Radiation Oncology Group (TROG) 04.01. Int J Radiat Oncol 2013;86:45-50, http://dx.doi.org/10.1016/j.ijrobp.2012.12.009.

[120] See A, Wright S, Denham JW. A pilot study of dermofilm in acute radiation-induced desquamative skin reactions. Clin Oncol R Coll Radiol G B 1998;10:182-5.

[121] MacBride SK, Wells ME, Hornsby C, Sharp L, Finnila K, Downie L. A case study to evaluate a new soft silicone dressing, Mepilex Lite, for patients with radiation skin reactions. Cancer Nurs 2008;31:E8-14, http://dx.doi.org/10.1097/01.NCC. 0000305680.06143.39.

[122] Diggelmann KV, Zytkovicz AE, Tuaine JM, Bennett NC, Kelly LE, Herst PM. Mepilex Lite dressings for the management of radiationinduced erythema: a systematic inpatient controlled clinical trial. $\mathrm{Br}$ J Radiol 2010;83:971-8, http://dx.doi.org/10.1259/bjr/62011713.

[123] Dean Paterson MJ, Prashika Poonam, Noelle C, XXX X, et al. Randomized intra-patient controlled trial of Mepilex Lite dressings versus aqueous cream in managing radiation-induced skin reactions postmastectomy. J Cancer Sci Ther 2012;4, http://dx.doi.org/10.4172/1948-5956.1000166.

[124] Herst PM, Bennett NC, Sutherland AE, Peszynski RI, Paterson DB, Jasperse ML. Prophylactic use of Mepitel Film prevents radiation-induced moist desquamation in an intra-patient randomised controlled clinical trial of 78 breast cancer patients. Radiother Oncol 2014;110:137-43, http://dx.doi.org/10.1016/j.radonc.2014.01.005.

[125] Aquino-Parsons C, Lomas S, Smith K, et al. Phase III study of silver leaf nylon dressing vs standard care for reduction of inframammary moist desquamation in patients undergoing adjuvant whole breast radiation therapy. J Med Imaging Radiat Sci 2010;41:215-21, http://dx.doi.org/10.1016/j.jmir.2010.08.005.

[126] Burch SE, Parker SA, Vann AM, Arazie JC. Measurement of 6MV X-ray surface dose when topical agents are applied prior to external beam irradiation. Int J Radiat Oncol 1997;38:447-51, http://dx.doi.org/10.1016/S0360-3016(97)00095-3.

[127] Li T, Perez-Soler R. Skin toxicities associated with epidermal growth factor receptor inhibitors. Target Oncol 2009;4:107-19, http://dx.doi.org/10.1007/s11523-009-0114-0.

[128] Tan EH, Chan A. Evidence-based treatment options for the management of skin toxicities associated with epidermal growth factor receptor inhibitors. Ann Pharmacother 2009;43:1658-66, http://dx.doi.org/10.1345/aph.1M241.

[129] Ocvirk J, Rebersek M. Management of cutaneous side effects of Cetuximab therapy with vitamin K1 crème. Radiol Oncol 2008;42:215-24, http://dx.doi.org/10.2478/v10019-008-0022-4.

[130] Ocvirk J, Rebersek M, Boc M, Mesti T, Ebert M. Prophylactic use of $\mathrm{K} 1$ cream for reducing skin toxicity during Cetuximab treatment 
in patients with metastatic colorectal cancer (mCRC). ASCO Meet Abstr 2010;28:e14011.

[131] Ocvirk J, Heeger S, McCloud P, Hofheinz R-D. A review of the treatment options for skin rash induced by EGFR-targeted therapies: evidence from randomized clinical trials and a metaanalysis. Radiol Oncol 2013;47:166-75, http://dx.doi.org/10.2478/raon-2013-0014.

[132] Radovics N, Kornek G, Thalhammer F, et al. Analysis of the effects of vitamin $\mathrm{K} 1$ cream on Cetuximab-induced acne-like rash. J Clin Oncol 2010:28.

[133] Yohn JJ, Weston WL. In: Weston WL, editor. Topical corticosteroids. Chicago: Year b. Med; 1990. p. 34-64

[134] Barnes PJ. How corticosteroids control inflammation: Quintiles Prize Lecture 2005. Br J Pharmacol 2006;148:245-54, http://dx.doi.org/10.1038/sj.bjp.0706736.

[135] Halnan KE. The effect of corticosteroids on the radiation skin reaction. A random trial to assess the value of local application of prednisolone and neomycin ointment after X-ray treatment of basal cell carcinoma. Br J Radiol 1962;35:403-8, http://dx.doi.org/10.1259/0007-1285-35-414-403.

[136] Boström A, Lindman H, Swartling C, Berne B, Bergh J. Potent corticosteroid cream (mometasone furoate) significantly reduces acute radiation dermatitis: results from a double-blind, randomized study. Radiother Oncol J Eur Soc Ther Radiol Oncol 2001;59:257-65.

[137] Shukla PN, Gairola M, Mohanti BK, Rath GK. Prophylactic beclomethasone spray to the skin during postoperative radiotherapy of carcinoma breast: a prospective randomized study. Indian J Cancer 2006;43:180-4.

[138] Omidvari S, Saboori H, Mohammadianpanah M, et al. Topical betamethasone for prevention of radiation dermatitis. Indian J Dermatol Venereol Leprol 2007;73:209.

[139] Miller RC, Schwartz DJ, Sloan JA, et al. Mometasone furoate effect on acute skin toxicity in breast cancer patients receiving radiotherapy: a phase iii double-blind, randomized trial from the north central cancer treatment group N06C4. Int J Radiat Oncol 2011;79:1460-6, http://dx.doi.org/10.1016/j.ijrobp.2010.01.031.

[140] Ulff E, Maroti M, Serup J, Falkmer U. A potent steroid cream is superior to emollients in reducing acute radiation dermatitis in breast cancer patients treated with adjuvant radiotherapy. A randomised study of betamethasone versus two moisturizing creams. Radiother Oncol 2013;108:287-92, http://dx.doi.org/10.1016/j.radonc.2013.05.033.

[141] Koukourakis GV, Kelekis N, Kouvaris J, Beli IK, Kouloulias VE. Therapeutics interventions with anti-inflammatory creams in post radiation acute skin reactions: a systematic review of most important clinical trials. Recent Pat Inflamm Allergy Drug Discov 2010;4:149-58.

[142] Salvo N, Barnes E, van Draanen J, et al. Prophylaxis and management of acute radiation-induced skin reactions: a systematic review of the literature. Curr Oncol 2010;17:94-112.

[143] Lacouture ME, Mitchell EP, Piperdi B, et al. Skin Toxicity Evaluation Protocol with Panitumumab (STEPP), a phase II, open-label, randomized trial evaluating the impact of a pre-emptive skin treatment regimen on skin toxicities and quality of life in patients with metastatic colorectal cancer. J Clin Oncol 2010;28:1351-7, http://dx.doi.org/10.1200/JCO.2008.21.7828.

[144] Gollins S, Gaffney C, Slade S, Swindell R. RCT on gentian violet versus a hydrogel dressing for radiotherapy-induced moist skin desquamation. J Wound Care 2008;17(268-70):274-5, 272.

[145] Macmillan MS, Wells M, MacBride S, Raab GM, Munro A, MacDougall H. Randomized comparison of dry dressings versus hydrogel in management of radiation-induced moist desquamation. Int $\mathrm{J}$ Radiat Oncol 2007;68:864-72, http://dx.doi.org/10.1016/j.ijrobp.2006.12.049.

[146] Vuong T, Franco E, Lehnert S, et al. Silver leaf nylon dressing to prevent radiation dermatitis in patients undergoing chemotherapy and external beam radiotherapy to the perineum. Int J Radiat Oncol Biol Phys 2004;59:809-14, http://dx.doi.org/10.1016/j.ijrobp.2003.11.031.
[147] Bone RC, Balk RA, Cerra FB, et al. Definitions for sepsis and organ failure and guidelines for the use of innovative therapies in sepsis. the ACCP/SCCM consensus conference committee. American college of chest physicians/society of critical care medicine. CHEST J 1992;101:1644-55, http://dx.doi.org/10.1378/chest.101.6.1644.

[148] Levy MM, Fink MP, Marshall JC, et al. 2001 SCCM/ESICM/ACCP/ATS/SIS International Sepsis Definitions Conference. Intensive Care Med 2003;29:530-8, http://dx.doi.org/10.1007/s00134-003-1662-x.

[149] Vincent J-L. Definition of sepsis and non-infectious SIRS. John Wiley \& Sons; 2008. p. 312 [Sepsis Non-Infect. Syst. Inflamm.]

[150] Mirabile A, Numico G, Russi EG, et al. Sepsis in head and neck cancer patients treated with chemotherapy and radiation: literature review and consensus. Crit Rev Oncol Hematol 2015, http://dx.doi.org/10.1016/j.critrevonc.03.003.

[151] Dellinger RP, Levy MM, Rhodes A, et al. Surviving Sepsis Campaign: International Guidelines for Management of Severe Sepsis and septic Shock, 2012. Intensive Care Med 2013;39:165-228, http://dx.doi.org/10.1007/s00134-012-2769-8.

[152] Robertson C, Robertson AG, Hendry JH, et al. Similar decreases in local tumor control are calculated for treatment protraction and for interruptions in the radiotherapy of carcinoma of the larynx in four centers. Int J Radiat Oncol 1998;40:319-29, http://dx.doi.org/10.1016/S0360-3016(97)00716-5.

[153] Rades D, Stoehr M, Kazic N, et al. Locally advanced stage IV squamous cell carcinoma of the head and neck: impact of pre-radiotherapy hemoglobin level and interruptions during radiotherapy. Int J Radiat Oncol 2008;70:1108-14, http://dx.doi.org/10.1016/j.ijrobp.2007.07.2380.

[154] Pratesi N, Mangoni M, Mancini I, et al. Association between single nucleotide polymorphisms in the XRCC1 and RAD51 genes and clinical radiosensitivity in head and neck cancer. Radiother Oncol 2011;99:356-61, http://dx.doi.org/10.1016/j.radonc.2011.05.062.

[155] Ambrosone CB, Tian C, Ahn J, et al. Genetic predictors of acute toxicities related to radiation therapy following lumpectomy for breast cancer: a case-series study. Breast Cancer Res BCR 2006;8:R40, http://dx.doi.org/10.1186/bcr1526.

[156] Rattay T, Talbot CJ. Finding the genetic determinants of adverse reactions to radiotherapy. Clin Oncol R Coll Radiol G B 2014;26:301-8, http://dx.doi.org/10.1016/j.clon.2014.02.001.

[157] Mangoni M, Bisanzi S, Carozzi F, et al. Association between genetic polymorphisms in the XRCC1, XRCC3, XPD, GSTM1, GSTT1, MSH2, MLH1, MSH3, and MGMT genes and radiosensitivity in breast cancer patients. Int J Radiat Oncol Biol Phys 2011;81:52-8, http://dx.doi.org/10.1016/j.ijrobp.2010.04.023.

[158] Zyla J, Finnon P, Bulman R, Bouffler S, Badie C, Polanska J. Seeking genetic signature of radiosensitivity - a novel method for data analysis in case of small sample sizes. Theor Biol Med Model 2014;11(Suppl. 1):S2, http://dx.doi.org/10.1186/1742-4682-11-S1-S2.

[159] Alterovitz G, Tuthill C, Rios I, Modelska K, Sonis S. Personalized medicine for mucositis: Bayesian networks identify unique gene clusters which predict the response to gammaD-glutamyl-L-tryptophan (SCV-07) for the attenuation of chemoradiation-induced oral mucositis. Oral Oncol 2011;47:951-5, http://dx.doi.org/10.1016/j.oraloncology.2011.07.006.

\section{Biographies}

Elvio G. Russi MD, (corresponding author) earned his M.D. degree at the University of Messina. He completed residency programmes in Radiation Oncology, in Medical Oncology, and in Radiodiagnosis. He is currently Head of the Radiation Oncology Department at Teaching Hospital 
"A.O. S. Croce e Carle" in Cuneo (Italy). Dr. Russi headed the "Head and neck study group" of Italian Association of Radiation Oncologist (AIRO) between 2012 and 2013. He was a board member for AIRO (Italian Association of Radiation Oncologist) between 2010 and 2012. He is the "elected president" of AIRO (2015). He has authored or co-authored over 85 original articles, book chapters with a predominant emphasis on Head and neck cancer treatment. "Author $\mathrm{H}$ index": 13 (Scopus 2014).

Marco C. Merlano MD, earned his M.D. degree at the University of Genoa. He is currently Chair of Oncological Department at Teaching Hospital "A.O. S. Croce e Carle" in Cuneo (Italy). Dr. Merlano has authored or co-authored over 135 original articles, book chapters with a predominant emphasis on Head and neck cancer treatment. "Author $\mathrm{H}$ index": 20 (Scopus 2014).

Lisa Licitra MD, is Chief of Head and neck cancer unit Istituto Nazionale dei Tumori Milano (Italy). She specialized in Medical Oncology at the University of Parma. Dr. Licitra was Chair of Head and neck cancer group of EORTC (European Organization For Research And Treatment Of Cancer) - member of PDQ (Physician's Data Query) of the National Cancer Institute USA. She is honorary member of European Society For Therapeutic Radiology And Oncology (ESTRO). Member of the editorial board - Cancer Treatment Reviews (2007-2009). She has authored or co-authored over 135 original articles, book chapters with a predominant emphasis on Head and neck cancer treatment. "Author H index": 27 (Scopus 2014).

Renè-Jean Bensadoun, MD, is currently Chief at Centre de Haute Energie in Nice. He was full professor of Radiation oncology at University of Poitiers, and Head of Department of Radiation Oncology at Centre Hospitalier Universitaire de Poitiers (France) between 2008 and 2014. He is Scientific Secretary of WALT (World Association for LaserTherapy),
Board Member of SFCCF and GORTEC (H \& N Cancer French Groups), Membre du CA de l'AFSOS (S. Support), Member of the Editorial Board of Journal of Supportive Cancer Care (Supp Care in Cancer), and Member of Mucositis Board and Oral Care Board of MASCC-ISOO. He has authored or co-authored over 140 original articles, book chapters with a predominant emphasis on Head and neck cancer treatment and supportive care in radiation oncology. "Author H index": 26 (Scopus 2014).

Girolomoni Giampiero, MD is Professor of Dermatology and Head of the Dermatology Section in the Department of Medicine at the University of Verona School of Medicine, Verona, Italy. He graduated from the University of Modena where he completed a residency programme in dermatology and venereology, and he was a Research Fellow and Visiting Instructor at the Department of Dermatology at the University of Texas Southwestern Medical School in Dallas, Texas, USA. He was also the Director of the Laboratory of Immunology, the Head of the Second Division of Dermatology and the Director of the Department of Clinical Dermatology at the Istituto Dermopatico dell'Immacolata in Rome, Italy. Professor Girolomoni is past president of the European Dermatology Forum, and president elect of the Italian Society of Dermatology (SIDeMaST). His scientific interests include skin manifestations of systemic diseases, skin diseases in immunocompromised patients, immunodermatology, immunology and immunopharmacology of atopic dermatitis and psoriasis. Prof. Girolomoni is co-author of more then 350 peer-reviewed articles, 70 book chapters, and 5 books. "Author H index": 58 (Scopus 2014).

Langendijk, Johannes A., MD, is Director of Department of Radiation Oncology, University Medical Centre Groningen, University of Groningen, Groningen, The Netherlands. He has authored or co-authored over 120 original articles, book chapters with a predominant emphasis on Head and neck cancer treatment. "Author H index": 33 (Scopus 2014). 